\title{
The effect of increasing doses of meat and bone meal (MBM) on maize (Zea mays L.) grown for grain
}

\author{
Anna Nogalska ${ }^{1}$, Jerzy Czapla ${ }^{1}$, Zenon Nogalski ${ }^{2}$, Małgorzata Skwierawska ${ }^{1}$ and Monika Kaszuba ${ }^{3}$ \\ ${ }^{1}$ Department of Agricultural Chemistry and Environmental Protection, ${ }^{2}$ Department of Cattle Breeding and Milk Quality Evalua- \\ tion, ${ }^{3}$ Experimental and Research Station \\ University of Warmia and Mazury in Olsztyn, ul. Oczapowskiego 8, 10-718 Olsztyn, Poland \\ e-mail: anna.nogalska@uwm.edu.pl
}

\begin{abstract}
The aim of this study was to determine the effect of meat and bone meal (MBM) used as an organic fertilizer on maize grown for grain. A two-factorial field experiment in a randomized block design was carried out in 2010 and 2011, in north-eastern Poland. Experimental factor I was MBM dose (1.0, 1.5, 2.0 and $2.5 \mathrm{t} \mathrm{ha}^{-1}$ year $\left.{ }^{-1}\right)$, and experimental factor II was the year of the study (two consecutive years). Increasing MBM doses contributed to an increase in maize grain yield and 1000-grain weight. The yield-forming effect of MBM applied at $1.5 \mathrm{t} \mathrm{ha}^{-1}$ year ${ }^{-1}$ was comparable with that of nitrogen and phosphorus contained in mineral fertilizers. A dose of $2.5 \mathrm{t} \mathrm{ha}^{-1} \mathrm{MBM}$ led to a significant increase in maize grain yield. The $\mathrm{P}$ and $\mathrm{K}$ content of maize grain was determined by $\mathrm{MBM}$ dose, whereas the concentrations of $\mathrm{N}, \mathrm{Mg}$ and $\mathrm{Ca}$ in grain were not affected by MBM dose. Significantly higher N, P, K and Mg uptake by maize plants was observed in treatments with the highest MBM dose, compared with the control treatment. Nitrogen and phosphorus uptake per $1 \mathrm{t} \mathrm{MBM}$ reached $101 \mathrm{~kg}$ and $26 \mathrm{~kg}$, respectively. The results of a twoyear study show that the maximum MBM dose $\left(2.5 \mathrm{t} \mathrm{ha}^{-1}\right.$ year $\left.^{-1}\right)$ met the fertilizer requirements of maize with respect to nitrogen and phosphorus.
\end{abstract}

Key words: grain yield, macronutrients, uptake, meat and bone meal

\section{Introduction}

Maize (Zea mays. L.) is the most widely grown grain crop, used for human consumption, animal feed and industrial purposes. The high yield potential of maize is determined by numerous factors, including breeding progress, climate conditions, soil conditions and fertilization. Maize is a thermophilous plant which has a high nutrient and water demand. In recent years, the levels of mineral fertilization have been relatively low in Poland due to economic reasons. Meat and bone meal is a rich source of nitrogen and phosphorus, as well as calcium, magnesium, microelements and organic substance, and therefore it can be a viable alternative to mineral fertilizers containing nitrogen and phosphorus (Górecka et al. 2009, Fernandes et al. 2010). Animal meals have been increasingly applied to improve soil fertility in recent years, because the EU banned the use of MBM as feed for animals and increased the prices of mineral fertilizers (Stępień and Mercik 2002, Chaves et al. 2005, Spychaj-Fabisiak et al. 2007, Fernandes et al. 2010). Jeng et al. (2004) stated that equivalence of MBM-N is $80 \%$ compared to that of mineral $\mathrm{N}$ fertilizer of grain crops.

International scientific literature provides scant information on the use of meat and bone meal in maize cultivation. The objective of this study was to evaluate the effect of meat and bone meal (MBM) used as an organic fertilizer on maize grown for grain. An attempt was also made to determine the optimum MBM dose in view of the nitrogen and phosphorus demand of maize.

\section{Material and methods}

A field experiment was carried out in 2010-2011 at the Research and Experimental Station in Bałdy, owned by the University of Warmia and Mazury in Olsztyn (NE Poland). The two-factorial experiment was performed in a randomized block design with four replications, on soil classified as Haplic Cambisols according to the FAO (2006) of the granulometric composition of loamy sand. The preceding crop was winter wheat. The soil used in the experiment had the following properties: $\mathrm{pH}_{\mathrm{KCl}}=6.2$, total organic $\mathrm{C} 7.72 \mathrm{~g} \mathrm{~kg}^{-1}$, total nitrogen $0.96 \mathrm{~g} \mathrm{~kg}^{-1}$, available 
phosphorus $49.2 \mathrm{mg} \mathrm{kg}^{-1}$, potassium $94.4 \mathrm{mg} \mathrm{kg}^{-1}$ and magnesium $32.0 \mathrm{mg} \mathrm{kg}^{-1} \mathrm{DM}$ of soil. The soil pH was determined in $1 \mathrm{~mol} \mathrm{KCl}$, total organic matter was determined by the Tiurin method, total nitrogen was determined by the Kjeldahl method, available phosphorus and potassium was determined by the Egner-Riehm method (DL), available magnesium by the Schachtschabel method (Panak 1997). Experimental plot area was $20 \mathrm{~m}^{2}$. In the first and second year of the study, maize was grown for grain var. 'San'.

The effect of increasing MBM doses $\left(1.0,1.5,2.0,2.5 \mathrm{t} \mathrm{ha}^{-1}\right.$ year $\left.{ }^{-1}\right)$ was compared with that of NPK fertilizers applied in the control treatment (recommended mineral fertilizer rates for maize: N-160 ${ }_{(60+50+50)}, \mathrm{P}-39, \mathrm{~K}-141 \mathrm{~kg}$ $\left.\mathrm{ha}^{-1}\right)$. The average amounts of nutrients supplied by mineral fertilizers and MBM are shown in Table 1.

Table 1. Doses of nitrogen (N), phosphorus (P) and potassium (K) $\left(\mathrm{kg} \mathrm{ha}^{-1}\right)$ applied with mineral fertilizers and meat and bone meal (MBM) for maize.

\begin{tabular}{l|lll|lll}
\hline \multirow{2}{*}{ Treatment } & \multicolumn{2}{|l}{ 2010 } & & \multicolumn{2}{l}{2011} & \\
\cline { 2 - 7 } & $\mathrm{N}$ & $\begin{array}{l}\mathrm{P} \\
\left(\mathrm{kg} \mathrm{ha}^{-1}\right)\end{array}$ & $\mathrm{K}$ & $\mathrm{N}$ & $\begin{array}{l}\mathrm{P} \\
\left(\mathrm{kg} \mathrm{ha}^{-1}\right)\end{array}$ & $\mathrm{K}$ \\
\hline Control NPK & 160.0 & 39.0 & 141.0 & 160.0 & 39.0 & 141.0 \\
$1.0 \mathrm{tMBM}+\mathrm{K}$ & 78.8 & 46.7 & 144.4 & 78.8 & 46.7 & 144.4 \\
$1.5 \mathrm{t} \mathrm{MBM+K}$ & 118.2 & 70.1 & 146.1 & 118.2 & 70.1 & 146.1 \\
$2.0 \mathrm{tMBM}+\mathrm{K}$ & 157.6 & 93.4 & 147.8 & 157.6 & 93.4 & 147.8 \\
$2.5 \mathrm{tMBM}+\mathrm{K}$ & 197.0 & 116.7 & 149.5 & 197.0 & 116.7 & 149.5 \\
\hline
\end{tabular}

According to the Regulation of the Minister of Agriculture and Rural Development of 7 December 2004 on the use of products of animal origin in organic fertilizers and soil improvers, MBM doses cannot exceed $5.0 \mathrm{t} \mathrm{ha} \mathrm{P}^{-1}$ over two years. The meal contained small amounts of potassium, which is why it was classified as a nitrogen-phosphorus fertilizer. Each year MBM was supplemented with potassium at a rate corresponding to potassium fertilizer levels in the control treatment. The meal used in the study was category 3 material which comprises animal by-products derived from the production intended for human consumption, and it was purchased from the Animal ByProducts Disposal Plant SARIA Poland in Długi Borek near Szczytno. MBM contained on average 96.05\% dry matter, $71.42 \%$ organic matter, $27.64 \%$ crude ash, 136.90 g crude fat, 78.80 g N, 46.71 g P, 3.42 g K, 100.30 g Ca, 6.81 $\mathrm{g} \mathrm{Na}$ and $2.00 \mathrm{~g} \mathrm{Mg} \mathrm{kg}^{-1}$. The meal contained only trace amounts of heavy metals, such as cadmium, chromium, lead, mercury and nickel, therefore it posed no health risk.

Grain yield, 1000-grain weight, mineral composition and macronutrient uptake by maize were determined. Plant samples were mineralized in concentrated sulfuric acid with hydrogen peroxide as the oxidizing agent. Wet mineralized samples were assayed for the content of total nitrogen - by the hypochlorite method, phosphorus - by the vanadium-molybdenum method, magnesium - by atomic absorption spectrometry (AAS), calcium and potassium - by atomic emission spectrometry (AES) (Panak 1997). The results were verified statistically by ANOVA using STATISTICA 10 software. The significance of differences between means was estimated by Duncan's test at $p<0.05$.

\section{Results and discussion}

As a thermophilous plant, maize is highly sensitive to adverse weather conditions during the growing season. In north-eastern Poland, characterized by a relatively harsh climate, maize is grown primarily for silage. In 2010, both temperatures and rainfall amounts were optimal for growing maize, with the exception of a cold and wet May when the temperature was $0.7^{\circ} \mathrm{C}$ lower and the rainfall was 2.5 -fold higher than the long-term average (Table 2). July and August, with temperatures around $3.0^{\circ} \mathrm{C}$ above the long-term average and sufficient precipitation, were conducive to cob development and ripening. The second year of the study (2011) was warmer than the first year average of $2{ }^{\circ} \mathrm{C}$ and compared to the long-term average of $3{ }^{\circ} \mathrm{C}$. 
Table 2. Average monthly temperatures $\left({ }^{\circ} \mathrm{C}\right)$ and total monthly rainfall $(\mathrm{mm}) 2010-2011$ according to the Research Station at Tomaszkowo.

\begin{tabular}{|c|c|c|c|c|c|c|}
\hline \multirow{2}{*}{ Month } & \multicolumn{3}{|c|}{ Average monthly air temperatures $\left({ }^{\circ} \mathrm{C}\right)$} & \multicolumn{3}{|c|}{ Total monthly rainfall $(\mathrm{mm})$} \\
\hline & 2010 & 2011 & 1970-2000 & 2010 & 2011 & 1970-2000 \\
\hline May & 12.0 & 15.7 & 12.7 & 131.9 & 61.4 & 51.9 \\
\hline June & 16.4 & 20.4 & 15.9 & 84.8 & 68.0 & 79.3 \\
\hline July & 21.1 & 20.7 & 17.7 & 80.4 & 184.8 & 73.8 \\
\hline August & 19.3 & 19.8 & 17.2 & 95.3 & 64.8 & 67.1 \\
\hline September & 12.0 & 14.2 & 12.5 & 40.5 & 31.2 & 43.4 \\
\hline Mean & 16.2 & 18.2 & 15.2 & 86.6 & 82.0 & 63.1 \\
\hline
\end{tabular}

The rainfall was unevenly distributed throughout the year 2011, which created less favorable conditions for maize growth and development. Rainfall excess in July (2.5-fold higher the long-term average) and rainfall deficiency in September accelerated kernel ripening.

The average grain yield for two years was $6.5 \mathrm{t} \mathrm{ha}^{-1}$ (Table 3). A similar maize yield was reported by Berzsenyi et al. (2000), while Berenguer et al. (2008) achieved a substantially higher grain yield $\left(12-14.6 \mathrm{t} \mathrm{ha}^{-1}\right)$ after the application of organic and mineral fertilizers. In our study, the highest MBM dose $\left(2.5 \mathrm{t} \mathrm{ha}^{-1}\right.$ year $\left.^{-1}\right)$ led to a significant increase in maize grain yield and 1000-grain weight (a difference of $1.29 \mathrm{t} \mathrm{ha}^{-1}$ and $10.8 \mathrm{~g}$, respectively, relative to the control treatment). The lowest MBM dose $\left(1 \mathrm{t} \mathrm{ha}^{-1}\right.$ year $\left.^{-1}\right)$ did not meet the nutrient requirements of maize, which resulted in a significant decrease in grain yield and grain quality, in comparison with the other treatments. Maize grain yield was significantly higher (by $1.26 \mathrm{t}$ ) and grains were plumper in the first year of the study (2010) than in the second year which was characterized by higher temperatures and uneven rainfall.

Table 3. Grain yield ( $\mathrm{t} \mathrm{ha}^{-1}$ ) and 1000-grain weight (TGW) of maize $(\mathrm{g})$, moisture $15 \%$. Values associated with the same letter are not significantly different $p<0.05$.

\begin{tabular}{|c|c|c|c|c|c|c|}
\hline \multirow{2}{*}{ Treatment } & \multicolumn{2}{|c|}{ Grain yield $\left(\mathrm{t} \mathrm{ha}^{-1}\right)$} & \multirow{2}{*}{$\begin{array}{l}\text { Mean for treatment } \\
\left(\mathrm{t} \mathrm{ha}^{-1}\right)\end{array}$} & \multicolumn{2}{|c|}{ TGW (g) } & \multirow{2}{*}{$\begin{array}{l}\text { Mean for treatmen } \\
\text { (g) }\end{array}$} \\
\hline & 2010 & 2011 & & 2010 & 2011 & \\
\hline Control NPK & 7.12 & 5.16 & $6.14 a$ & 265.2 & 254.5 & $259.8 a b$ \\
\hline $1.0 \mathrm{t} \mathrm{MBM}+\mathrm{K}$ & 6.25 & 4.79 & $5.52 b$ & 253.4 & 253.9 & $253.7 a$ \\
\hline $1.5 \mathrm{t} \mathrm{MBM+K}$ & 7.03 & 5.92 & $6.48 a$ & 263.9 & 257.8 & $260.9 a b$ \\
\hline $2.0 \mathrm{tMBM}+\mathrm{K}$ & 7.55 & 5.53 & $6.54 a$ & 268.9 & 258.3 & $263.6 b c$ \\
\hline $2.5 \mathrm{t} \mathrm{MBM}+\mathrm{K}$ & 7.31 & 7.54 & $7.43 c$ & 273.4 & 267.9 & $270.6 c$ \\
\hline Mean for years & $7.05 a$ & $5.79 b$ & - & $265.0 a$ & $258.5 b$ & - \\
\hline
\end{tabular}

Over a two-year experimental period, correlations were observed between an increase in MBM doses and an increase in maize grain yield and 1000-grain weight, but only the lowest MBM dose decreased grain yield, in comparison with the control treatment. The yield-forming effect of MBM applied at $1.5 \mathrm{t} \mathrm{ha}^{-1}$ year ${ }^{-1}$ was comparable with that of mineral fertilizers. The maximum MBM dose $\left(2.5 \mathrm{t} \mathrm{ha}^{-1}\right.$ year $\left.{ }^{-1}\right)$, which had the most beneficial influence on grain yield, did not exceed the allowed maximum amount of animal origin fertilizer by national legislation. A positive effect of MBM on crop yield was also noted by other authors (Salomonsson et al. 1994, Valenzuela et al. 2000, Stępień and Mercik 2002, Jeng et al. 2004, 2006, Chaves et al. 2005, Ylivainio et al. 2008, Górecka et al. 2009, Sempiterno et al. 2010, Chen et al. 2011, Nogalska 2011, Nogalska et al. 2011). 
The use of MBM led to an insignificant decrease in the nitrogen content of maize grain, relative to the control, which ranged from 17.01 to $19.25 \mathrm{~g} \mathrm{~kg}^{-1}$ (Table 4). In a study by Berenguer et al. (2008), the nitrogen content of maize grain varied between 11.3 and $17.1 \mathrm{~g} \mathrm{~kg}^{-1}$. In our experiment, only the highest MBM dose supplied provided the amount of nitrogen comparable with that noted in control plants. However, Jeng et al. (2004) stated that equivalence of MBM-N is $80 \%$ compared to that of mineral $\mathrm{N}$ fertilizer of grain crops. In our study, the highest nitrogen uptake was also observed following the application of MBM at the maximum dose (Table 5). Nutrient uptake by crops is one of the most important criteria for fertilizer evaluation, and it is estimated based on the biomass produced and the content of a given nutrient in biomass. Maize grain harvested in 2011 contained higher amounts of nitrogen, despite a considerably lower yield, most probably due to higher availability of soil nitrogen released by mineralization of animal protein that had not been broken down in the previous year.

Table 4. Macroelement content of the grain of maize in different MBM treatments $\left(\mathrm{g} \mathrm{kg}^{-1}\right)$. Values associated with the same letter are not significantly different $p<0.05$.

\begin{tabular}{|c|c|c|c|c|c|c|c|}
\hline Macroelement & Year & Control NPK & $1,0 \mathrm{t} \mathrm{BM}+\mathrm{K}$ & $\begin{array}{l}1,5 \mathrm{t} \mathrm{BM}+\mathrm{K} \\
\left(\mathrm{g} \mathrm{kg}^{-1}\right)\end{array}$ & $2,0 \mathrm{t} \mathrm{BM}+\mathrm{K}$ & $2,5 \mathrm{t} \mathrm{BM}+\mathrm{K}$ & $\begin{array}{l}\text { Mean } \\
\text { for years }\end{array}$ \\
\hline \multirow{3}{*}{$N$} & 2010 & 16.35 & 14.99 & 10.60 & 15.46 & 15.18 & $14.52 a$ \\
\hline & & & & & & & \\
\hline & 2011 & 24.28 & 21.89 & 23.43 & 19.46 & 23.31 & $22.48 b$ \\
\hline Mean for dose & & 20.32 & 18.44 & 17.01 & 17.46 & 19.25 & - \\
\hline \multirow{3}{*}{$P$} & 2010 & 4.21 & 4.32 & 4.36 & 4.29 & 4.46 & $4.33 a$ \\
\hline & & & & & & & \\
\hline & 2011 & 4.60 & 4.62 & 4.75 & 4.65 & 5.20 & $4.82 b$ \\
\hline Mean for dose & & $4.55 a$ & $4.47 a$ & $4.55 a$ & $4.47 a$ & $4.83 b$ & - \\
\hline \multirow{2}{*}{ K } & 2010 & 3.88 & 4.02 & 4.02 & 4.06 & 3.84 & $3.96 a$ \\
\hline & 2011 & 6.17 & 6.29 & 6.34 & 6.79 & 7.08 & $6.53 b$ \\
\hline Mean for dose & & $5.03 a$ & $5.15 \mathrm{ac}$ & $5.18 \mathrm{ac}$ & $5.43 b c$ & $5.46 b$ & - \\
\hline \multirow[b]{2}{*}{ Mg } & 2010 & 1.40 & 1.31 & 1.34 & 1.34 & 1.47 & $1.37 a$ \\
\hline & 2011 & 1.79 & 1.90 & 1.87 & 1.88 & 2.09 & $1.91 b$ \\
\hline Mean for dose & & 1.60 & 1.60 & 1.61 & 1.61 & 1.78 & - \\
\hline \multirow{3}{*}{$\mathrm{Ca}$} & 2010 & 0.28 & 0.29 & 0.24 & 0.25 & 0.22 & $0.26 a$ \\
\hline & & & & & & & \\
\hline & 2011 & 0.43 & 0.37 & 0.37 & 0.40 & 0.41 & $0.40 \mathrm{~b}$ \\
\hline Mean for dose & & 0.36 & 0.33 & 0.30 & 0.32 & 0.32 & - \\
\hline
\end{tabular}

The mean phosphorus content of maize grain ranged from 4.47 to $4.83 \mathrm{~g} \mathrm{~kg}^{-1}$, subject to MBM dose. Maize fertilized with the highest dose of MBM was characterized by a significantly higher phosphorus content of grain, compared with the other treatments, which resulted from the highest phosphorus uptake from soil fertilized $2.5 \mathrm{t}$ $\mathrm{MBM} \mathrm{ha}^{-1}$. Phosphorus uptake by plants was higher in 2010, due to a higher yield rather than a higher phosphorus supply. It should be noted that MBM can be a rich source of available phosphorus for maize plants already in the first year of application. An increase in the phosphorus content of grasses fertilized with MBM was also observed by Ylivainio et al. (2008), Nogalska (2011) and Nogalska et al. (2011). 
Table 5. Uptake of macroelements in maize (whole plants) in different MBM treatments ( $\left.\mathrm{kg} \mathrm{ha}^{-1}\right)$. Values associated with the same letter are not significantly different $p<0.05$.

\begin{tabular}{|c|c|c|c|c|c|c|c|}
\hline Macroelement & Year & Control NPK & $1.0 \mathrm{t} \mathrm{MBM}+\mathrm{K}$ & $\begin{array}{l}1.5 \mathrm{t} \mathrm{MBM}^{-\mathrm{K}} \\
\left(\mathrm{kg} \mathrm{ha}^{-1}\right)\end{array}$ & $2.0 \mathrm{t} \mathrm{MBM+K}$ & $2.5 \mathrm{t} \mathrm{MBM}+\mathrm{K}$ & $\begin{array}{l}\text { Mean for } \\
\text { years }\end{array}$ \\
\hline \multirow[b]{2}{*}{$\mathrm{N}$} & 2010 & 193.7 & 147.8 & 125.4 & 196.6 & 193.1 & 171.3 \\
\hline & 2011 & 159.4 & 148.9 & 201.5 & 156.1 & 251.7 & 183.5 \\
\hline Mean for dose & & $176.5 a$ & $148.4 a$ & $163.4 a$ & $176.3 a$ & $222.4 b$ & - \\
\hline \multirow{2}{*}{$P$} & 2010 & 49.7 & 44.8 & 50.4 & 53.3 & 52.2 & $50.1 \mathrm{a}$ \\
\hline & 2011 & 32.1 & 31.8 & 38.9 & 36.1 & 58.0 & $39.4 b$ \\
\hline Mean for dose & & $40.9 a b$ & $38.3 a$ & $44.7 \mathrm{~b}$ & $44.7 b$ & $55.1 \mathrm{c}$ & - \\
\hline \multirow[b]{2}{*}{$\mathrm{K}$} & 2010 & 209.5 & 195.6 & 216.2 & 238.8 & 227.3 & $217.5 a$ \\
\hline & 2011 & 119.0 & 145.5 & 175.6 & 161.1 & 236.0 & $167.4 b$ \\
\hline Mean for dose & & $164.3 a$ & $170.5 a$ & $195.9 \mathrm{~b}$ & $200.0 \mathrm{~b}$ & $231.6 c$ & - \\
\hline \multirow[b]{2}{*}{ Mg } & 2010 & 16.7 & 13.5 & 16.3 & 17.5 & 18.6 & $16.5 a$ \\
\hline & 2011 & 11.4 & 11.3 & 14.1 & 13.1 & 20.3 & $14.0 \mathrm{~b}$ \\
\hline Mean for dose & & 14.0ab & $12.4 a$ & $15.2 b$ & $15.3 b$ & $19.4 c$ & - \\
\hline \multirow[b]{2}{*}{$\mathrm{Ca}$} & 2010 & 54.0 & 42.0 & 50.8 & 61.1 & 55.5 & $52.7 a$ \\
\hline & 2011 & 38.3 & 36.8 & 38.0 & 37.5 & 43.8 & $38,9 b$ \\
\hline Mean for dose & & 46.1 & 39.4 & 44.4 & 49.3 & 49.6 & - \\
\hline
\end{tabular}

The potassium content of maize grain varied in years, from 3.96 to $6.53 \mathrm{~g} \mathrm{~kg}^{-1}$. Quite surprisingly, the potassium content of grain and potassium uptake by maize plants were significantly higher in plots fertilized with higher MBM doses, in comparison with the control treatment. In all treatments (including those fertilized with MBM), $170 \mathrm{~kg}$ $\mathrm{K}$ was applied as $60 \%$ potash salt, while one ton of MBM provides only $3.4 \mathrm{~kg} \mathrm{~K}$. According to Csatho (2002), potassium accumulation in plants is determined mostly by weather conditions, maize variety and an optimum supply of nitrogen and phosphorus.

The concentrations of magnesium and calcium in maize grain were not affected by MBM dose. Maize plants contained significantly higher amounts of magnesium and calcium in the second year of the study, despite higher uptake of both nutrients in the first year. Large uptake of $\mathrm{Ca}$ and $\mathrm{Mg}$ by maize in the first year was a result of the increased yield and straw richer in? macroelements compared to the second year of the study. The maximum MBM dose (2.5 t) contributed to the highest magnesium uptake, which resulted in its highest accumulation in grain. As demonstrated by Górecka et al. (2009), macronutrient concentrations and uptake by spring rapeseed plants fertilized with MBM were comparable with those noted following the application of mineral fertilizers. Similar results were reported by Sempiterno et al. (2010), Jeng et al. (2004, 2006), Nogalska (2011) and Nogalska et al. (2011) for other crop species.

Total nitrogen uptake by maize plants over a two-year experimental period ranged from $296.7 \mathrm{~kg}$ in the treatment with the lowest MBM dose to $444.8 \mathrm{~kg}$ after the application of the highest MBM dose (Table 6). Increased uptake of the main macronutrients resulted from a higher grain yield and higher nitrogen concentrations in grain, but even the highest nitrogen content of MBM and mineral fertilizers did not fully correspond to nitrogen amounts in yield. 
Table 6. Calculated cumulative nitrogen (N) and phosphorus (P) balance for the years $2010-2011$

\begin{tabular}{|c|c|c|c|c|c|c|}
\hline \multirow{2}{*}{ Treatment } & \multicolumn{3}{|c|}{$\mathrm{N}\left(\mathrm{kg} \mathrm{ha}^{-1}\right)$} & \multicolumn{3}{|c|}{$\mathrm{P}\left(\mathrm{kg} \mathrm{ha}^{-1}\right)$} \\
\hline & dose & uptake & balance & dose & uptake & balance \\
\hline Control NPK & 320.0 & 353.1 & -33.1 & 78.0 & 81.8 & -3.8 \\
\hline $1.0+1.0$ t MBM+K & 157.6 & 296.7 & -139.1 & 93.4 & 76.6 & 16.8 \\
\hline $1.5+1.5$ t MBM+K & 236.4 & 326.9 & -90.5 & 140.2 & 89.3 & 50.9 \\
\hline $2.0+2.0$ t MBM+K & 315.2 & 352.7 & -37.5 & 186.8 & 89.4 & 97.4 \\
\hline $2.5+2.5 \mathrm{t} \mathrm{MBM}+\mathrm{K}$ & 394.0 & 444.8 & -50.9 & 233.4 & 110.2 & 123.2 \\
\hline
\end{tabular}

The lowest difference between nitrogen uptake and supply was found in NPK - fertilized plots $\left(-33.1 \mathrm{~kg} \mathrm{ha}^{-1}\right)$. A slightly higher nitrogen deficiency, at a higher grain yield, was observed after the application of 4 and $5 \mathrm{t}$ MBM over two years ( -37.5 and $-50.9 \mathrm{~kg} \mathrm{~N} \mathrm{ha}^{-1}$, respectively). As expected, the highest nitrogen deficiency was noted in the treatment with the lowest MBM dose $\left(-139.1 \mathrm{~kg} \mathrm{~N} \mathrm{ha}^{-1}\right)$. Nitrogen and phosphorus uptake per $1 \mathrm{t} \mathrm{MBM}$ reached $101 \mathrm{~kg}$ and $26 \mathrm{~kg}$, respectively. Total phosphorus uptake ranged from $76.6 \mathrm{~kg}$ in the treatment with the lowest MBM dose to $110.2 \mathrm{~kg}$ in the treatment with the highest MBM dose; a similar trend was observed with regard to nitrogen balance. Phosphorus balance was positive in all treatments, and lower phosphorus uptake from MBM than from mineral fertilizers was noted only at the lowest MBM dose. According to previous studies (Jeng et al. 2006, Spychaj-Fabisiak et al. 2007, Valenzuela et al. 2000) meat and bone meal, because of low phosphorous availability in the first growing period, can be treated a main source of this nutrient for plants grown in the next seasons. These authors do not recommend soil application of phosphorus in the next season after MBM was applied. However, there is a contrasting opinion given by Fernandes et al. (2010) who warned against application of high rates of meat and bone meal (above $6.0 \mathrm{t} \mathrm{ha}^{-1}$ ) particularly on sandy and acid soils because too much available phosphorus can be then released that can result in ground water pollution and euthrophisation of surface waters. From results of our own studies it can be concluded that application of relatively high rate of MBM (2.5 $t \mathrm{ha}^{-1}$ ) to maize led to nitrogen deficit and accumulation of high amounts of phosphorus. Therefore it seems reasonable to combine lower MBM rates with mineral nitrogen.

Perception of meat and bone meals as organic soil amendments has to be considered as proofed method when economical as well environmental aspects are taken into consideration because they can supply crops in N, P and $\mathrm{Ca}$ and are able to increase humus content in soils. Through agricultural utilization of animal wastes, harmful deposit and the high cost of disposal by incineration could be avoided.

\section{References}

Berenguer, P., Santiveri, F., Boixadera, J. \& Lloveras, J. 2008. Fertilisation of irrigated maize with pig slurry combined with mineral nitrogen. European Journal of Agronomy 28: 635-645.

Berzsenyi, Z., Győrffy, B. \& Lap, D. 2000. Effect of crop rotation and fertilisation on maize and wheat yields and yield stability in a long-term experiment. European Journal of Agronomy 13: 225-244.

Chaves, C., Canet, R., Albiach, R., Marin, J. \& Pomares, F. 2005. Meat and bone meal: fertilizing value and rates of nitrogen mineralization. Nutrient and Carbon Cycling in Sustainable Plant-Soil Systems 1(6-9): 177-180.

Chen, L., Kivelä, J., Helenius, J. \& Kangas, A. 2011. Meat bone meal as fertiliser for barley and oat. Agricultural and Food Science 20: 235-244.

Csatho, P. 2002. The residual effect of $\mathrm{K}$ fertilization in a Hungarian corn monoculture long- term field trial. 1990-1999. Communication in Soil Science and Plant Analysis 33: 3105-3119.

FAO, 2006. World Reference Base for Soil Resources. World Soil Resources Report 103: 1-128. Food and Agriculture Organization of the United Nations, Rome, Italy.

Fernandes, R., Sempiterno, C. \& Calouro, F. 2010. Meat and bone meal as nitrogen and phosphorus supplier to ryegrass (Lolium multiflorum L. var. Helen); II - Effects on soil N and P levels. Treatment and use of organic residues in Agrculture: Challenges and opportunitites towards sustainable management. 14 ${ }^{\text {th }}$ Ramiran International Conferece Lisbon 12-15 September 2010.

Górecka, H., Sztuder, H. \& Sienkiewicz-Cholewa, U. 2009. Agricultural usefulness of fertilization products obtained from the utilization of wastes from animal production. Zeszyty Problemowe Postępów Nauk Rolniczych 537: 125-133. (in Polish). 
Jeng, A.S., Haraldsen, T.K., Vagstad, N. \& Grønlund, N. 2004. Meat and bone meal as nitrogen fertilizer to cereals in Norway. Agricultural and Food Science 13: 268-275.

Jeng, A.S., Haraldsen, T.K., Grønlund, A. \& Pedersen, P.A. 2006. Meat and bone meal as nitrogen and phosphorus fertilizer to cereals and ryegrass. Nutrient Cycling in Agroecosystems 76: 183-191.

Nogalska, A. 2011. The effect of increasing doses of meat and bone meal on the yield and macronutrient content of timothy grass (Phleum pratense L.). Fertilizers and Fertilization 43: 58-66. (in Polish).

Nogalska, A., Czapla, J. \& Skwierawska, M. 2011. The effect of increasing doses of meat-and-bone meal on the yield and macronutrient content of perennial ryegrass (Lolium perenne L.). Polish Journal of Natural Sciences 26(1): 5-13. (in Polish).

Panak, H. 1997. Metodical Guide to Agricultural Chemistry. Wydawnictwo ART Olsztyn. (in Polish).

Salomonsson, L., Jonsson, A., Salomonsson, A.C. \& Nilsson, G. 1994. Effects of organic fertilizers and urea when appied to spring wheat. Acta Agriculture Scandinavica Section B, Soil and Plant Science 44(3): 170-178.

Sempiterno, C., Fernandes, R. \& Calouro, F. 2010. Meat and bone meal as nitrogen and phosphorus supplier to ryegrass (Lolium multiflorum L. var. Helen); I - Dry matter yield. $\mathrm{N}$ and $\mathrm{P}$ uptake and apparent $\mathrm{N}$ and $\mathrm{P}$ recovery. Treatment and use of organic residues in Agrculture: Challenges and opportunitites towards sustainable management. $14^{\text {th }}$ Ramiran International Conferece Lisbon 12-15 September 2010.

Spychaj-Fabisiak, E., Kozera, W., Majcherczak, E., Ralcewicz, M. \& Knapkowski, T. 2007. Evaluation of light soil fertility after the application of organic wase and manure. Acta Scientarium Polonorum Agricultura 6(3): 69-76. (in Polish).

Stępień, W. \& Mercik, S. 2002. Fertilization value of animal product processing wastes. Zeszyty Problemowe Postępów Nauk Rolniczych 484: 595-600. (in Polish).

Valenzuela, H.R., Goo, T., Randall, H., Hamasaki, R.H. \& Radovich, T. 2000. The effect of bone meal on the yield of jicama. Pachyrhizus Erosus. in Oahu Hawaii. Proceedings of the Florida State Hortticultural Society 113: 222-226.

Ylivainio, K., Uusitalo, R. \& Turtola, E. 2008. Meat and bone meal and fox manure as P source for ryegrass (Lolium multiflorum) grown on a limed soil. Nutrient Cycling in Agroecosystems 81(3): 267-278. 